\title{
Adenylate cyclase activity of bovine spermatozoa during maturation in the epididymis and the activation of sperm particulate adenylate cyclase by GTP and polyamines
}

\author{
E. R. Casillas, C. M. Elder* and D. D. Hoskins* \\ Department of Chemistry, New Mexico State University, Las Cruces, New Mexico, 88003, \\ U.S.A., and ${ }^{*}$ Department of Reproductive Physiology, Oregon Regional Primate Research \\ Center, Beaverton, Oregon, 97005, U.S.A.
}

\begin{abstract}
Summary. The adenylate cyclase activity of bovine caput and cauda epididymal spermatozoa was measured in intact- and in broken-cell preparations. Cyclase activity was 4 -fold greater in caput than in cauda cells and total cyclase activity in broken-cell preparations was 3-5 times greater than that in intact cells. A particulate fraction derived from sonically disrupted caput spermatozoa was used to study the effects of compounds that might be physiologically important modulators of adenylate cyclase. Activity was stimulated by GTP, 5-guanylyl imidophosphate and by the polyamines, spermine and spermidine.
\end{abstract}

\section{Introduction}

The concentration of cyclic adenosine $3^{\prime}-5^{\prime}$-monophosphate (cAMP) increases in bovine spermatozoa as they pass through, and mature in, the epididymis (Hoskins, Stephens \& Hall, 1974). Evidence that the increase in vivo may be physiologically important is provided by the observation that the difference in cAMP content between caput and cauda spermatozoa, approximately $60 \mathrm{pmol} / 10^{9}$ cells, is greater than the increase in sperm cAMP levels that occurs when motility is induced in bovine cauda spermatozoa by caffeine (Garbers, First \& Lardy, 1973). Besides its possible role in the maturation process, cAMP has been implicated in other physiological sperm functions such as metabolism, motility, and capacitation (Hoskins \& Casillas, 1975). Tash \& Mann (1973) have shown that the cellular levels of cAMP represent a sensitive indicator of the onset of senescence changes in spermatozoa. In an attempt to understand how cAMP levels in spermatozoa are regulated, we are studying the properties of the enzymes that catalyse cAMP synthesis (adenylate cyclase: EC 4.6.1.1) and cAMP breakdown (cAMP phosphodiesterase: EC 3.1.4.17).

Previous studies of adenylate cyclase in spermatozoa are few and most have been conducted with intact, mature (ejaculated or from the cauda epididymidis) cells (Hoskins \& Casillas, 1975). Here we report the results of studies on the enzyme in spermatozoa from the caput and cauda epididymidis. 


\section{Materials and Methods}

Testes from mature bulls were obtained from local meat processors on the morning of slaughter and were delivered to the laboratory as soon as possible. Spermatozoa from at least 12 organs were collected from the distal caput and cauda epididymal regions and the samples were prepared for study by established procedures (Casillas, 1973).

Adenylate cyclase activity in intact spermatozoa in crude, broken-cell preparations, and in freshly prepared particulate fractions obtained from broken-cell preparations was measured by the methods described by Casillas \& Hoskins $(1970,1971)$ with minor modifications. In the modified procedure $\left[\alpha^{-32} \mathrm{P}\right]$ ATP was used as substrate rather than $\left[{ }^{14} \mathrm{C}\right] \mathrm{ATP}$, papaverine $(5 \mathrm{mM})$ was substituted for theophylline as a cAMP phosphodiesterase inhibitor, and the final concentration of $\mathrm{MgCl}_{2}$ was $5.0 \mathrm{mM}$. Unless otherwise noted, each mixture contained 32 units of pyruvate kinase and $25 \mathrm{~mm}$-phosphoenolpyruvate. Cyclase activity is expressed in terms of the number of spermatozoa present in the assay mixture or, when partly purified preparations were used, the number from which the sample was prepared. All assays were performed with fresh preparations because attempts to store them have been unsuccessful.

Broken-cell preparations were obtained by irradiating suspensions of spermatozoa with sound waves (Biosonik III: Bronwill Scientific, Rochester, New York, U.S.A.) at an intensity setting of 20 . In this procedure, spermatozoa, $1 \times 10^{9} / \mathrm{ml}$, were suspended in an ice-cold medium consisting of $20 \mathrm{mM}-\mathrm{NaH}_{2} \mathrm{PO}_{4}, 119 \mathrm{mM}-\mathrm{NaCl}, 5 \mathrm{mM}-\mathrm{KCl}(\mathrm{pH} 7 \cdot 0$ ), and were irradiated for 2 min in 30 -sec bursts with 2 -min cooling periods between irradiations.

Particulate fractions which contained relatively large amounts $(20-40 \%)$ of the total adenylate cyclase activity, but relatively small amounts of the total cAMP phosphodiesterase activity, were obtained in the following manner. Caput spermatozoa were suspended $\left(1 \times 10^{9}\right.$ cells $/ \mathrm{ml})$ in ice-cold hypotonic media $\left(10 \mathrm{mM}^{-\mathrm{KH}_{2}} \mathrm{PO}_{4}, \mathrm{pH} \mathrm{7.4)}\right.$ for 10 min to disrupt the plasma membrane (Keyhani \& Storey, 1973). The ionic strength of the suspension was then increased by the addition of one volume of $1.13 \mathrm{M}-\mathrm{KCl}, 0.4 \mathrm{M}-\mathrm{Tris}-\mathrm{HCl}, \mathrm{pH} 7 \cdot 4$, to 9 volumes of the suspension. This suspension was irradiated with sound for $30 \mathrm{sec}$, as described above, and then centrifuged ( $10000 \mathrm{~g}$ for $10 \mathrm{~min}$ ). The supernatant solution was collected and centrifuged again (105 $000 \mathrm{~g}$ for $60 \mathrm{~min})$. After discarding the supernatant solution the precipitated particles were suspended in a suitable volume of the phosphate-buffered salt solution.

Cyclic AMP phosphodiesterase activity was assayed by the radioisotopic method of Thompson \& Appleman (1971) as modified by Kakiuchi, Yamasaki, Teshima, Ueniski \& Miyamoto (1975) and by Stephens, Wang \& Hoskins (1979).

The ATP content of various incubation mixtures was measured by the luciferin-luciferase assay of Stanley \& Williams (1969) as modified by Brooks (1970).

ATP, GTP, 5-guanylyl imidophosphate, phosphoenolpyruvate, pyruvate kinase (400-500 units/mg protein), phosphocreatine, creatine kinase (100-150 units/mg protein) and papaverine were purchased from Sigma Chemical Co., St. Louis, Missouri, U.S.A., and $\left[\alpha{ }^{32}\right.$ P]ATP (sp. act. 10-30 Ci/mmol) from New England Nuclear, Boston, Massachusetts, U.S.A. All other chemicals were of the highest grade obtainable from commercial sources.

\section{Results}

\section{Adenylate cyclase activity of cauda and caput spermatozoa}

Results presented in Text-fig. 1 show that suspensions of sonically irradiated spermatozoa contained enzymes that catalyse the rapid degradation of ATP. These data also show that in similar suspensions that contain either phosphoenolpyruvate-pyruvate kinase or a phosphocreatine-creatine kinase ATP-regenerating system, ATP levels remain relatively constant for 20 min, the standard incubation period of an adenylate cyclase assay. Additional studies show that 


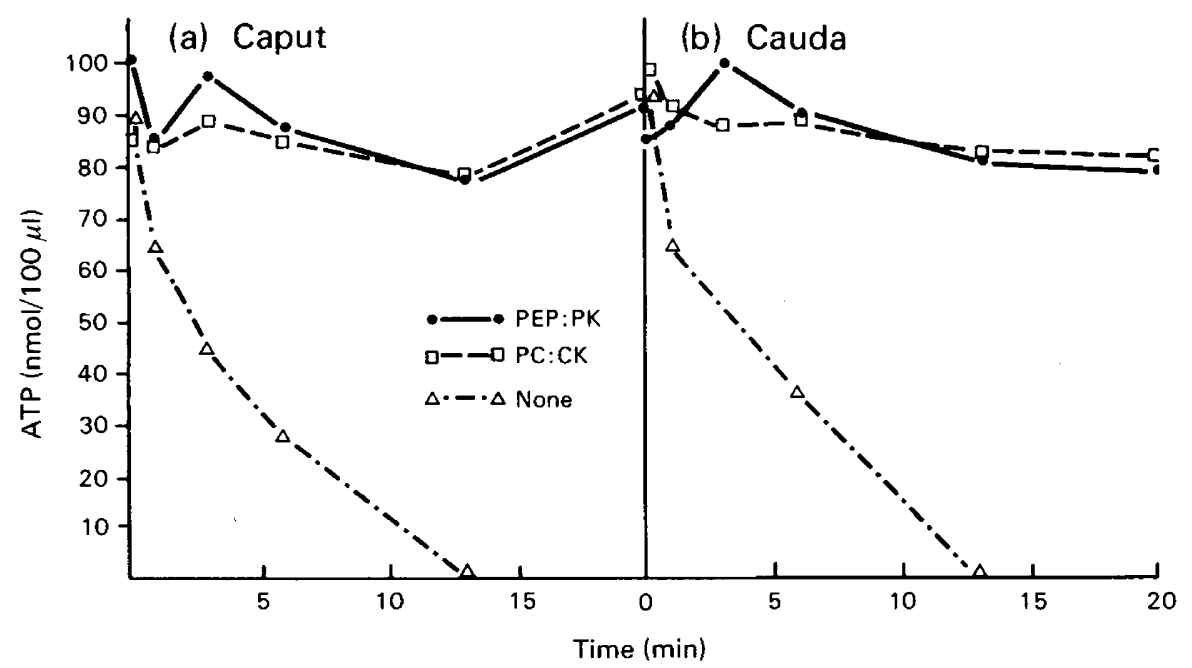

Text-fig. 1. ATP concentrations in the adenylate cyclase assay mixtures in the presence and absence of ATP-regenerating systems. In addition to the standard reaction components ('Methods'), each reaction mixture contained 1 mM-ATP and (a) $8.8 \times 10^{7}$ sonified but unfractionated caput spermatozoa or (b) $1.3 \times 10^{8}$ sonified but unfractionated cauda spermatozoa; and 32 units pyruvate kinase with 25 mM-phosphoenolpyruvate (PEP:PK) or 35 units creatine kinase with $25 \mathrm{~mm}$ phosphocreatine $(P C: C K)$. Control incubations $(\triangle)$ did not contain an ATP-regenerating system. Each point is the average of 3 determinations. The variation from the mean was $<10 \%$ in each case.

cAMP production by broken-cell preparations from both caput and cauda spermatozoa, measured in the presence of either ATP-regenerating system, was linear with respect to time for $20 \mathrm{~min}$ and with respect to cell number from $1.5 \times 10^{7}$ to $2.5 \times 10^{8}$ spermatozoa (data not shown). The coefficients of determination and slope values for activity against time were 0.948 and $2.28 \mathrm{pmol} / 10^{8}$ cells $/ \mathrm{min}$ for caput spermatozoa and 0.963 and $0.58 \mathrm{pmol} / 10^{8}$ cells $/ \mathrm{min}$ for cauda spermatozoa. The coefficients of determination and slope values for activity against cell numbers was 0.993 and $5.62 \mathrm{pmol} / 20 \mathrm{~min} / 10^{7}$ cells for caput and 0.995 and $2.46 \mathrm{pmol} / 20$ $\mathrm{min} / 10^{7}$ cells for cauda spermatozoa.

The adenylate cyclase activity ( $\mathrm{pmol} / 10^{9}$ cells $/ 20 \mathrm{~min}$ ) of caput spermatozoa was $3 \cdot 5-4.5$ times greater than that of cauda spermatozoa for intact (130 \pm 15 (s.e.m.) and $37 \pm 2, n=4$, respectively) and sonically disrupted $(927 \pm 106$ and $203 \pm 16, n=4$, respectively) cells. When compared directly in the same experiment, activity in the broken-cell preparations was always 3-5 times greater than in the intact-cell suspensions. The activities in both kinds of preparations were stimulated about 40 -fold by $5 \mathrm{mM}-\mathrm{Mn}^{2+}$ but were not affected by $10 \mathrm{~mm}-\mathrm{F}^{-}$(data not shown).

\section{Effect of GTP and Gpp $(N H)$ p on partly purified adenylate cyclase from caput spermatozoa}

Guanosine triphosphate (GTP) activated enzyme activity in partly purified, particulate preparations obtained from caput spermatozoa. The response to increasing concentrations of GTP was biphasic (Text-fig. 2a). Low concentrations (10-40 $\mu \mathrm{M})$ increased the activity at least 2-fold (Text-fig. 2b) whereas concentrations above $250 \mu \mathrm{M}$ inhibited the enzyme (Text-fig. 2a). The GTP analogue, 5-guanylylimidophosphate [Gpp(NH)p], which is resistant to hydrolysis catalysed by guanosine triphosphatase and which stimulates adenylate cyclases from other cells (Rodbell et al., 1975), also activated the sperm enzyme. Different concentrations of Gpp(NH)p gave results similar to those with GTP; activation was observed with concentrations ranging from 10 to $50 \mu \mathrm{M}$ and 2- to 8-fold maximal stimulation was observed with $30 \mu \mathrm{M}$ (Text-fig. $2 \mathrm{c}$ ). 


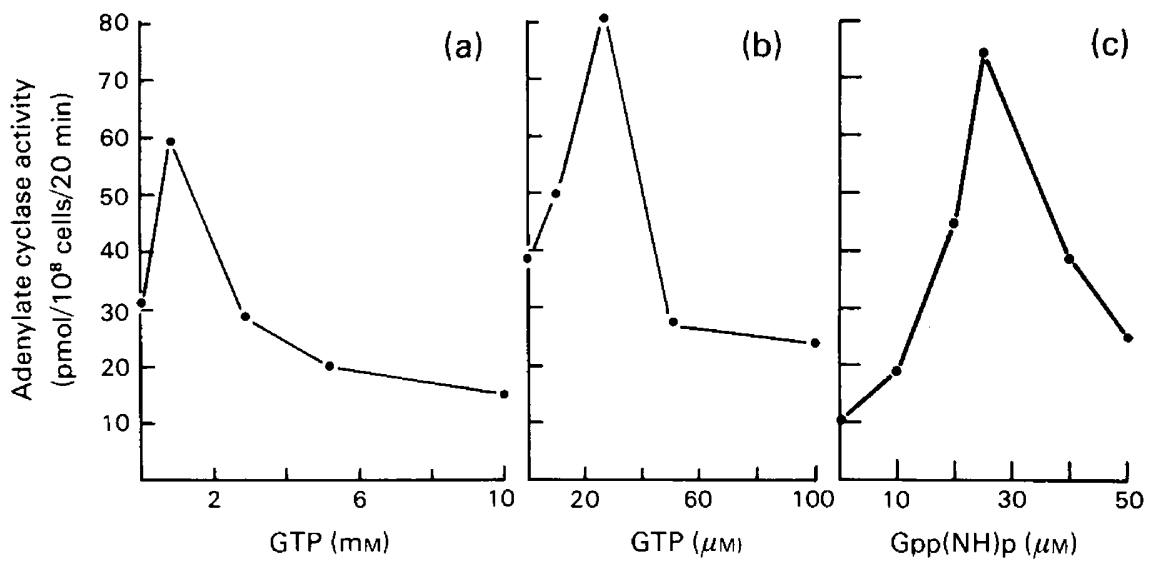

Text-fig. 2. Effect of different concentrations of GTP (a, b) and Gpp(NH)p (c) on adenylate cyclase activity, measured as described in 'Methods'. Each incubation mixture contained the $105000 \mathrm{~g}$ pellet derived from $4 \times 10^{8}$ caput spermatozoa. The results are from typical experiments and each point is the average of 3 determinations. The variation from the mean was $<10 \%$ in each case.

\section{Effects of polyamines on partly purified adenylate cyclase from caput spermatozoa}

Adenylate cyclase preparations $\left(4.5 \times 10^{8}\right.$ spermatozoa $)$ were incubated with 25 $\mu \mathrm{M}-\mathrm{GPP}(\mathrm{NH}) \mathrm{p}$ and with or without $1 \mathrm{~mm}$-polyamine. All 3 polyamines increased adenylate cyclase activity (338 pmol $/ 10^{9}$ cells $/ 20 \mathrm{~min}$ when no added polyamine) and the effects of spermine $(980 \mathrm{pmol})$ and spermidine $(990 \mathrm{pmol})$ were more potent than that of putrescine $(687$ pmol). In another experiment the effects of spermidine, $\mathrm{Gpp}(\mathrm{NH}) \mathrm{p}$, and combinations of the two were tested. The activity was $93 \mathrm{pmol} / 10^{9} \mathrm{cells} / 20 \mathrm{~min}$ in the absence of activators, $175 \mathrm{pmol}$ with $1 \mathrm{~mm}$-spermidine, $214 \mathrm{pmol}$ with $30 \mathrm{mM}$-Gpp(NH)p and 321 pmol with a combination of $30 \mathrm{~mm}$-Gpp(NH)p and $1 \mathrm{~mm}$-spermidine. Each of the above values is the average from triplicate incubations and the variability between triplicate determinations was $<10 \%$. These results indicate that both $\mathrm{Gpp}(\mathrm{NH}) \mathrm{p}$ and spermidine activate adenylate cyclase activity and that the effects are additive. Dose-response experiments with spermidine alone gave typical saturationtype curves with a half-maximal response with $0.1 \mathrm{mM}$-spermidine. The maximal stimulation varied from 1.5- to 2-fold between separate experiments. Poly-L-lysine at concentrations ranging from 0.5 to $100 \mathrm{~mm}$ had no effect on the sperm enzyme.

\section{Discussion}

Measurements of sperm adenylate cyclase activity have usually been performed with intact cells. In this procedure, cells are incubated with radioactive ATP and phosphodiesterase inhibitors and radioactive CAMP formation is measured. An obvious disadvantage of the method is that permeability barriers may limit the accessibility of the substrate and (or) modulators to the total enzyme pool. In our earlier studies with ejaculated monkey spermatozoa (Casillas \& Hoskins, 1970,1971 ) we tried to circumvent this problem by disrupting cells with sonic irradiation, but this technique also released a very potent ATPase which rapidly hydrolysed ATP and made the assay of adenylate cyclase more difficult. These difficulties included not only unacceptably low ATP concentrations after a short incubation period, but also high concentrations of radinaciively labelled intermediates which were difficult to separate completely from labelled cAMP. Both difficulties were minimized with intact cells and cAMP production was linear with time of incubation and with the amount of cells within specific limits. In preparation for the studies described here, we selected ATP-regenerating systems to be used with broken-cell 
preparations on the basis of their ability to maintain ATP concentrations at a constant level under optimal adenylate cyclase assay conditions. The results obtained with broken-cell and intact-cell preparations, show that the intact-cell procedure underestimates the total cyclase activity present in spermatozoa by at least a factor of 3 . The enzyme is several times more active in caput than in cauda spermatozoa regardless of whether intact or broken cells are assayed. These results indicate that the increase in the cAMP content of spermatozoa that accompanies their maturation in the bovine epididymis is not determined by the basal level of adenylate cyclase activity in the cells as measured here. It may be that sperm cAMP levels during maturation are regulated primarily by the activity of cAMP phosphodiesterase, the activity of which is greater in caput than in cauda bovine spermatozoa (Stephens et al., 1979). It is also possible that other factors are involved in the regulation of cAMP levels in vivo and that these factors are not accounted for in our in-vitro assay techniques.

Although mammalian spermatozoa contain the main components of the 'cAMP second messenger system', attempts to identify modulators of adenylate cyclase that are clearly physiologically important have not been successful (Hoskins \& Casillas, 1975), perhaps because most of the early studies were performed with mature intact spermatozoa whose cyclase may not have been exposed to optimum concentrations of substrate or modulators. Our results show that the partly purified, particulate adenylate cyclase from functionally immature spermatozoa from the caput epididymidis is activated by GTP and its analogue Gpp(NH)p. This preparation could therefore be used to test the effects of compounds that might be physiologically important, especially if the cAMP system is involved in the maturation process.

To our knowledge, the present results are the first to report that guanine nucleotides stimulate the adenylate cyclase of mammalian spermatozoa. Zahler \& LeGrand (1977) have reported that GTP inhibits the soluble form of adenylate cyclase obtained from bovine spermatozoa. Their results are not directly comparable to those presented here since we have studied a form of the enzyme that is bound to subcellular particles. Furthermore, the concentrations of guanine nucleotides which stimulated cyclase activity in the present experiments $(10-100 \mu \mathrm{M})$ are less than those tested by Zahler \& LeGrand (1977). Activation by GTP is a property of adenylate cyclases from many mammalian spermatozoa and other eukaryotic cells (Rodbell et al., 1975: Ingeyar, Swartz \& Birnbaumer, 1979). In systems that have been extensively studied, e.g. liver, hormones and GTP act synergistically in activating adenylate cyclase. Hence, our observation that the sperm enzyme is activated by GTP may be useful in the identification of other physiological modulators of the sperm cyclase and, furthermore, may help us discover the precise function of cAMP in mammalian spermatozoa.

Shah, Sheth, Mugatwala \& Rao (1975) reported that the adenylate cyclase activity of human ejaculated spermatozoa is increased when these cells are incubated in vitro with spermine. This report coupled with the knowledge that high concentrations of spermine and spermidine are present in the seminal plasma of some species (Mann, 1964) and that polyamines are present in bovine epididymal spermatozoa in concentrations ranging from 0.3 to $10 \mathrm{~mm}$ for spermidine and 2 to $15 \mathrm{~mm}$ for spermine (Bamberg, Weiser \& Desser, 1975; intrasperm concentrations were estimated by assuming a sperm volume of $36 \mu \mathrm{m}^{3}$, Drevius, 1972) prompted us to investigate whether these compounds affect bovine spermatozoan adenylate cyclase activity. Our results show that the bovine enzyme is activated by spermidine and putrescine. The effect does not appear to be a general one due to polycations because poly-L-lysine at concentrations reported to stimulate beef thyroid adenylate cyclase (Wolf \& Cook, 1975) had no effect on the sperm enzyme. Unlike the effects of some hormones on the adenylate cyclase in their target cells (Rodbell et al., 1975), spermidine did not appear to act synergistically with GTP in activating the sperm enzyme. Together, our results with polyamines and GTP indicate that these compounds may be involved in the regulation of sperm cAMP concentrations. The precise function of these compounds in spermatozoa awaits the elucidation of the role(s) of cAMP in sperm physiology. 
This work was supported by grants from the National Institutes of Health (HD05969, RR00163, HD10664).

\section{References}

Bamberg, E., Weiser, M. \& Desser, H. (1975) Polyamines in bovine epididymal spermatozoa. $J$. Reprod. Fert. 45, 363-365.

Brooks, D.E. (1970) Observations on the content of ATP and ADP in bull spermatozoa using the firefly luciferase system. J. Reprod. Fert. 23, 525-528.

Casillas, E.R. (1973) Accumulation of carnitine by bovine spermatozoa during maturation in the epididymis. J. biol. Chem. 248, 8227-8232.

Casillas, E.R. \& Hoskins, D.D. (1970) Activation of monkey spermatozoal adenyl cyclase by thyroxine and triiodothyronine. Biochem. Biophys. Res. Commun. 40, 255-262.

Casillas, E.R. \& Hoskins, D.D. (1971) Adenyl cyclase activity and cyclic 3',5'-AMP content of ejaculated monkey spermatozoa. Archs Biochem. Biophys. 147, $148-155$.

Drevius, L.O. (1972) Bull spermatozoa as osmometers. J. Reprod. Fert. 28, 29-39.

Garbers, D., First, N.L. \& Lardy, H.A. (1973) The stimulation of bovine epididymal sperm metabolism by cyclic nucleotide phosphodiesterase inhibitors. Biol. Reprod. 8, 589-598.

Hoskins, D.D. \& Casillas, E.R. (1975) Hormones, second messengers and the mammalian spermatozoa. In Advances in Sex Hormone Research, Vol. 1, Molecular Mechanisms of Gonadal Hormone Action, pp. 283-324. Eds R. L. Singhal \& J. A. Thomas, University Park Press, Baltimore.

Hoskins, D.D., Stephens, D.T. \& Hall, M.L. (1974) Cyclic adenosine $3^{\prime}, 5^{\prime}$-monophosphate and protein kinase levels in developing bovine spermatozoa. $J$. Reprod. Fert. 37, 131-133.

Ingeyar, R., Swartz, T.L. \& Birnbaumer, L. (1979) Coupling of glucagon receptor to adenylyl cyclase: requirements of a receptor-related guanyl nucleotide binding site for coupling of receptor to the enzyme. $J$. biol. Chem. 254, 1119-1123.

Kakiuchi, S., Yamasaki, R., Teshima, Y., Ueniski, K. \& Miyamoto, E. (1975) Multiple cyclic nucleotide phosphodiesterase activities from rat tissues and occurence of a calcium-plus magnesium ion-dependent phosphodiesterase and its protein activator. Biochem. J. 146, 109-120.

Keyhani, E. \& Storey, B.T. (1973) Oxidation rates of Krebs cycle carboxylic acids by the mitochondria of hypotonically treated rabbit epididymal spermatozoa. Fert. Steril. 24, 864-871.

Mann, T. (1964) The Biochemistry of Semen and the Male Reproductive Tract, pp. 194-200. Methuen, London.

Rodbell, M., Lin, M.C., Saloman, Y., Londos, C., Harwood, J.P., Martin, B.C., Rendell, M. \& Berman, M. (1975) Role of adenine and guanine nucleotides in the activity and response of adenylate cyclase system to hormones: Evidence for multisite transition states. Adv. Cyclic Nucleotides Res. 5, 3-29.

Shah, G.V., Sheth, A.R., Mugatwala, P.P. \& Rao, S.S. (1975) Effect of spermine on adenyl cyclase activity of spermatozoa. Experientia 15, 631-632.

Stanley, P.E. \& Williams, S.G. (1969) Use of the liquid scintillation spectrometer for determining adenosine triphosphate by the luciferase enzyme. Analyt. Biochem. 29, 381-392.

Stephens, D.T., Wang, J.L. \& Hoskins, D.D. (1979) The phosphodiesterase of bovine spermatozoa: multiple forms, kinetic properties and changes during development. Biol. Reprod. 20, 483-491.

Tash, J.S. \& Mann, T. (1973) Adenosine 3':5'-cyclic monophosphate in relation to motility and senescence of spermatozoa. Proc. $R$. Soc. Lond. $B$ 184, 109-114.

Thompson, W.J. \& Appleman, M.M. (1971) Multiple cyclic nucleotide phosphodiesterase activities from rat brain. Biochemistry, $N . Y .10,311-316$.

Wolf, J. \& Cook, G.H. (1975) Charge effects in the activation of adenylate cyclase. J. biol. Chem. 250, 6897-6903.

Zahler, W.L. \& LeGrand, R.D. (1977) Studies on soluble adenylate cyclase from bull sperm. Fedn Proc. Fedn Am. Socs exp. Biol. 36, 685, Abstr.

Received 7 August 1979 